\title{
Editorial: Eudaimonia and Music Learning
}

\author{
Gareth Dylan Smith ${ }^{1 *}$, Marissa Silverman ${ }^{2}$ and Dylan van der Schyff ${ }^{3}$ \\ ${ }^{1}$ Music Education Department, Boston University, Boston, MA, United States, ${ }^{2}$ Music Education Department, Montclair State \\ University, Montclair, NJ, United States, ${ }^{3}$ Conservatorium of Music, The University of Melbourne, Parkville, VIC, Australia
}

Keywords: editorial, music, learning, eudaimonia, flourishing

\section{Editorial on the Research Topic \\ Eudaimonia and Music Learning}

This special topic came about in response to a recent surge in interest and scholarship around the combined themes of eudaimonia and music learning. In a way, musicians, music teachers, and scholars of music learning have always been writing about eudaimonia and music learning; they just have not always phrased it as such. Music learning is an obvious and necessary topic of discussion for musicians, teachers, and community music practitioners. It is a very diverse field, including the broad range of perspectives and practices that fall under the rubric of "music education" (a term understood and interpreted as variously as the international contexts in which it is used) and much more. Eudaimonia is probably less familiar to some, since writing on this term is far sparser. As contributors to this special topic have noted elsewhere, eudaimonia is a concept that began its life with Plato and Aristotle, and has been interpreted according to prevailing paradigms in Western secular and religious thought ever since (Boyce-Tillman, 2020; Silverman, 2020a; Smith and Silverman, 2020; van der Schyff, 2020). Eudaimonism-the ethos of or orientation to eudaimonia-is an ethical frame that focuses on human flourishing or thriving. It

OPEN ACCESS

Edited and reviewed by: Gyorgy Fazekas, Queen Mary University of London, United Kingdom

*Correspondence:

Gareth Dylan Smith gdsmith@bu.edu

Specialty section:

This article was submitted to Educational Psychology,

a section of the journal

Frontiers in Psychology

Received: 02 July 2021 Accepted: 19 July 2021 Published: 18 August 2021

Citation:

Smith GD, Silverman M and van der Schyff D (2021) Editorial: Eudaimonia and Music Learning.

Front. Psychol. 12:735393.

doi: 10.3389/fpsyg.2021.735393 is a concept that runs through literature on positive psychology (Seligman, 2011), connected with research happiness, with fulfillment-based conceptions eudaimonia often differentiated from the more immediate gratification and pleasures of hedonic happiness (Deci and Ryan, 2008). Writing on eudaimonia tends to focus either more on individual purpose and self-fulfillment (Norton, 1976; Waterman, 1992; Smith, 2016) or more on collective well-being and the responsibilities of learners, educators, and facilitators in that regard; music education scholars have tended to write more on the latter (Elliott and Silverman, 2014, 2015; Elliott, 2020).

While in a way, this special topic broaches little that is startlingly new, it curates a space for papers by like-minded thinkers and writers who find the eudaimonic frame to be helpful. The content of this special topic is far from comprehensive in its purview, which as editors and scholars in this domain we find exciting, hopeful that readers might find this an area generative of further thinking themselves.

In June Boyce-Tillman's paper-“Heart's ease: Eudaimonia, musicking and the pandemic and its implications for music education"-the author discusses themes in the eudaimonia literature, comprising ethical behavior, a sense of meaning and purpose, contemplation, relationship with spirits of the ancestors and celestial beings, and relationships of mutuality and respect. She then discusses, in the context of the COVID-19 pandemic, how music educators have adopted and enacted these values, before suggesting ways in which music teaching and learning can continue to grow.

In their paper titled "Flourishing in resonance: Joint resilience building through music and motion," Luc Nijs and Georgia Nicolaou situate their work by discussing connections between conceptions of resilience and eudaimonia. They go on to describe how musical activities founded 
in movement practices can help young people to develop and experience eudaimonic values that include self-awareness, confidence and self-esteem, personal autonomy, connection, belonging, and bonding.

What are the aims, purposes, and perceptions of older musicians who participate in blues jam sessions? In "Jammin' the Blues: Experiencing the 'Good Life," Debrot examines and analyzes how eudaimonic well-being results from life-long musicing. Moreover, because of the participatory nature of the jam sessions, and because participatory musicing yields agency and collective self-other direction, adult music makers at The Tavern on the Hill expanded their social, cultural, and musical identities in profound and meaningful ways.

Meanwhile, Hendricks et al., in "Caring For, About, and With: Exploring Musical Meaningfulness Among Suzuki Students and Parents," examined parent-child shared music learning experiences through Suzuki training, and how such music making and sharing might assist in the development of empathy, connectivity, and relationality between parents and their children. The authors note, "music learning, human connections, and shared values work together to reinforce musical meaningfulness, potentially creating a self-perpetuating eudaimonic circle."

In "A Space for Collaborative Creativity: How Collective Improvising Shapes a Sense of Belonging," Verneert et al., examine the eudaimonic potential and potencies of adult music makers, namely during collective musical improvisational experiences. The community under examination, here, was homeless adults as well as individuals with emotional, psychological, and cognitive challenges. For these individuals

\section{REFERENCES}

Boyce-Tillman, J. (2020). "An ecology of eudaimonia and its implications for music education," in Eudaimonia: Perspectives for Music Learning, eds G. D. Smith and M. Silverman (New York, NY: Routledge), 71-89. doi: $10.4324 / 9780429264948-7$

Deci, E. L., and Ryan, R. M. (2008). The "what" and "why" of goal pursuits: human needs and the self-determination of behavior. Psychol. Inquiry 11, 227-268. doi: 10.1207/S15327965PLI1104_01

Elliott, D. E. (2020). "Eudaimonia and well-doing: implications for music education," in Eudaimonia: Perspectives for Music Learning, eds G. D. Smith and M. Silverman (New York, NY: Routledge), 107-120. doi: 10.4324/9780429264948-9

Elliott, D. J., and Silverman, M. (2014). Music, personhood, and eudaimonia: Implications for educative and ethical music education. J. Transdiscip. Res. Southern Africa 10, 59-74. doi: 10.4102/td.v10i2.99

Elliott, D. J., and Silverman, M. (2015). Music Matters: A Philosophy of Music Education, 2nd edition. New York, NY: Oxford University Press.

Norton, D. L. (1976). Personal Destinies: A Philosophy of Ethical Individualism. Princeton, NJ: Princeton University Press.

Seligman, M. E. P. (2011). Flourish: A Visionary New Understanding of Happiness and Well-Being. New York, NY: Simon and Shuster.

Silverman, M. (2020a). "The hull house: a case study in eudaimonia for music learning," in Eudaimonia: Perspectives for Music Learning, eds G. D. Smith and M. Silverman (New York, NY: Routledge), 30-44. doi: $10.4324 / 9780429264948-3$

Silverman, M. (2020b). Sense-making, meaningfulness and instrumental music education. Front. Psychol. 11:837. doi: 10.3389/fpsyg.2020.00837

Smith, G. D. (2016). "(Un)popular music making and eudaimonia," in The Oxford Handbook of Music Making and Leisure, eds R. Mantie and G. D. Smith (Oxford University Press), 151-170. doi: 10.1093/oxfordhb/9780190244705.013.31 engaged in non-formal, community musicing, the researchers found results such as a sense of belonging, "flow" (or optimal experience), meaningfulness (see also Silverman, 2020b), as well as accomplishment and satisfaction.

Smith's contribution-"Music education for surviving and thriving: Cultivating children's wonder, senses, emotional wellbeing, and wild nature as a means to discover and fulfill their life's purpose"-develops connections between the eudaimonic perspective and eco-literate music pedagogy. Smith draws on insights from ecological philosophy, soundscape studies, and more to show how these mutually supporting orientations can help to dismantle the "logic of domination" that pervades modern life. She then discusses how musical praxis informed by this critical shift in thinking can "encourage children (and all people) to maintain their sense of wonder in nature, to fully develop their sensory capacities, to support their psychospiritual well-being, and to foster soulcentric maturation."

Walzer's paper, "Fostering trauma-informed and eudaimonic pedagogy in music education," takes a look through several theoretical lenses at what he describes as a praxis of care in music education. Beginning in the context of music making and learning during the COVID-19 pandemic, Walzer urges music educators to consider a eudaimonic pedagogy, based in humility, confidence, and a nurturing, loving approach to music teaching and learning.

\section{AUTHOR CONTRIBUTIONS}

All authors listed have made a substantial, direct and intellectual contribution to the work, and approved it for publication.

Smith, G. D., and Silverman, M. (2020). "Eudaimonia: Flourishing through music learning," in Eudaimonia: Perspectives for Music Learning, eds G. D. Smith and M. Silverman (New York, NY: Routledge), 1-13. doi: 10.4324/97804292 64948

van der Schyff, D. (2020). "Music education and the continuity of mind and life," in Eudaimonia: Perspectives for Music Learning, eds G. D. Smith and M. Silverman (New York, NY: Routledge), 14-29. doi: 10.4324/97804292 64948-2

Waterman, A. S. (1992). "Identity as an aspect of optimal psychological functioning," in The Inner Level: How More Equal Societies Reduce Stress, Restore Sanity and Improve Everyone's Well-Being, eds G. R. Adams, T. P. Wilkinson, and K. Pickett (London: Penguin Press), 50-72.

Conflict of Interest: The authors declare that the research was conducted in the absence of any commercial or financial relationships that could be construed as a potential conflict of interest.

Publisher's Note: All claims expressed in this article are solely those of the authors and do not necessarily represent those of their affiliated organizations, or those of the publisher, the editors and the reviewers. Any product that may be evaluated in this article, or claim that may be made by its manufacturer, is not guaranteed or endorsed by the publisher.

Copyright (c) 2021 Smith, Silverman and van der Schyff. This is an open-access article distributed under the terms of the Creative Commons Attribution License (CC $B Y)$. The use, distribution or reproduction in other forums is permitted, provided the original author(s) and the copyright owner(s) are credited and that the original publication in this journal is cited, in accordance with accepted academic practice. No use, distribution or reproduction is permitted which does not comply with these terms. 